\title{
156a. Untersuchungen über den Einfluß der Algennahrung auf den Eiweißhaushalt bei Intensivpflegefällen
}

\author{
G. BerkHoFF* und G. Kramer-Dortmund
}

Investigations on the Effect of Algae Feeding on the Protein Metabolism in Intensive Care Cases

Summary. Since attempts to compensate completely the protein loss in intensive care patients by infusions and administration of concentrated food mixtures must be regarded as unsatisfactory, clinical trials were undertaken with the feeding of algae (green alga Scenedesmus). Altogether 300 patients received algae by stomach tube or as additional food for an average of 14-18 days after preliminary tests had shown that the normal protein requirements of an adult can be covered by $100 \mathrm{~g}$ dried algae. Results so far, as shown in clinical studies, are sufficiently encouraging to recommend a wider use of the method.

Zusammenfassung. Da bisherige Versuche, bei Intensivbehandlungspatienten den Eiweißverlust dureh Infusionen und Zufuhr konzentrierter Nahrungsgemische vollständig $\mathrm{zu}$ decken, als unbefriedigend angesehen werden müssen, wurden klinische Versuche mit der Verfütterung von Algen (Grünalge Scenedesmus) unternommen. Insgesamt erhielten 300 Patienten Algen als Sondennahrung oder Beikost für durchschnittlich 14-18 Tage, nachdem sich in Vorversuchen nachweisen ließ, daB der normale Eiweißbedarf eines Erwachsenen mit $100 \mathrm{~g}$ Algentrockensubstanz pro Tag zu decken ist. Die bisherigen Erfahrungen sind, wie klinische Verlaufsstudien zu erkennen geben, so ermutigend, daß eine breitere Anwendung dieser Methode empfohlen werden kann.

\section{6b. Die Ernährung bewußtloser Schwerkranker in der Neurochirurgie}

\author{
B. VILAND*, W. J. BoCK und J. LIESEGANG-Essen \\ Feeding of Unconscious Patients in Neuro-Surgery
}

Summary. The caloric requirements of patients with serious craniocerebral injuries are ca. $4000-5000$ cal per day. To cover these requirements by parenteral feeding large quantities of fluid would have to be infused, with the danger of cerebral oedema and overloading of the circulation. Moreover, certain substances (e. g. fats), if infused relatively too rapidly, would lead to a high serum concentration, exceed the renal threshold and no longer act on the metabolism. In contrast to parenteral feeding, tube feeding requires only $2500 \mathrm{ml}$ fluid. A special composition of this tube feed, with a proportion of fat slightly below the ideal value, is discussed. For elinical practice it is suggested to start with purely parenteral feeding because of the usually present atony of the gastrointestinal tract and the associated enzyme disturbance, and to change gradually to tube feeding from the 3rd day onwards. 